\title{
EXISTENCE OF DEGENERATING CELLS IN THE SEMINIFEROUS TUBULES OF THE NORMAL, ADULT AND RETROGRESSED TESTES OF THE INDIAN HEDGEHOG, PARAECHINUS MICROPUS
}

\author{
PUSHPAMALA BIDWAI AND S. R. BAWA \\ Department of Biophysics, Panjab University, \\ Chandigarh, India
}

(Received 20th March 1970, revised 19th May 1971)

Recently, cells showing cytochemical reactions which differ from those of the normal cells of the seminiferous tubules and which appear to resemble degenerating cells have been described in mammalian testes subjected to hyperthermic shock or treated with alkylating agents (Steinberger \& Dixon, 1959; Steinberger, 1962; Chowdhary \& Steinberger, 1964). Chowdhary \& Steinberger (1970) suggested that the appearance of PAS-positive material in the cytoplasm of the degenerating spermatocytes followed by pycnosis of their nuclei was the expression of the metabolic damage caused by hyperthermic shock. These authors also described another type of cell degeneration in testes exposed to heat treatment at $43^{\circ}$ to $45^{\circ} \mathrm{C}$ when the spermatid nuclei revealed classical pycnotic changes before the appearance of abnormal cytochemical reactions.

We have observed degenerating cells with PAS-positive cytoplasm in the seminiferous tubules of the normal, sexually active and retrogressed adult testes of the Indian hedgehog. These cells appeared to be randomly distributed and their cytoplasm, which was apparently devoid of any inclusions, stained homogeneously with trichrome (PI. 1, Fig. 1), iron haematoxylin, eosin and light green. Their cellular protein material was non-granular in appearance and was uniformly dispersed in the cytoplasm, as indicated by positive mercury bromophenol blue (Pl. 1, Fig. 2) and coupled tetrazolium reactions (Pearse, 1961). The presence of mucoproteins and mucopolysaccharides in the uniformly PAS-positive cytoplasm (Pl. 1, Fig. 3) was revealed by a positive Mayer's mucicarmine test (Pl. 1, Fig. 4). A negative Alcian blue reaction suggested that the polysaccharides were not acidic. The absence of glycogen was demonstrated by negative Bauer Feulgen and Best's carmine reactions. Intense staining with pyronin gallocyanin and iron haematoxylin (Pl. 1, Fig. 5) indicated that the cells were rich in RNA. Their cytoplasm was Sudan black B positive, both in paraffin wax (Pl. 1, Fig. 6) and gelatin preparations but the cells close to or already discharged into the lumen of the seminiferous tubules contained free lipid droplets in their cytoplasm (P1. 1, Fig. 7). The cells were deficient in both alkaline (Pl. 1, Fig. 8) and acid phosphatase activity.

Hedgehogs are seasonally breeding mammals possessing intra-abdominal 
testes so that the question of temperature variation of the testes does not arise as long as the body temperature is constant. The cells described in this communication maintain their cytochemical identity in the seminal fluid in the epididymis. It is difficult to explain the persistent occurrence of such cells in both the normal and retrogressed adult testes and also in the seminal plasma of the hedgehogs in the absence of exposure to heat or to treatment with alkylating agents. The presence of cytoplasmic mucoproteins, mucopolysaccharides and lipids, on the other hand, suggests that the cells might have some secretory rôle to play in the economy of the testes and the seminal fluid.

\section{REFERENCES}

Chowdhary, A. K. \& Steinberger, E. (1964) A quantitative study of the effect of heat on the germinal epithelium of rat testis. Am. F. Anat. 115, 509.

Chowdhary, A. K. \& Steinberger, E. (1970), Early changes in the germinal epithelium of rat testes following exposure to heat. F. Reprod. Fert. 22, 205.

Pearse, A. G. V. (1961) Histochemistry, theoretical and applied. Little, Brown and Co., Boston.

STEINBERGER, E. (1962) A quantitative study of the effect of an alkylating agent (triethylenemelamine) on the seminiferous epithelium of rats. F. Reprod. Fert. 3, 250.

Strinberger, E. \& Dixon, W. J. (1959) Some observations on the effect of heat on the testicular germinal epithelium. Fert. Steril. 10, 578.

\section{EXPLANATION OF PLATE 1}

All the figures are from testicular material of the adult hedgehog.

Fio. 1. Darkly staining degenerating cells (Dc) Mason's trichrome, $\times 280$.

Frg. 2. The degenerating cell cytoplasm is uniformly and intensely stained. Mercury bromophenol blue, $\times 280$.

FrG. 3. Degenerating cells are distinctly discernible amongst the spermatogonia, primary spermatocytes (spc), spermatids (spd) and Sertoli cells (Sc). Hime's and Moriber, $\times 700$.

FIG. 4. Degenerating cells located in the lumen of the seminiferous tubules. Mucicarmine, $\times 280$.

FIG. 5. The degenerating spermatids show homogeneously staining cytoplasm. Iron haematoxylin, $\times 700$.

Fic. 6. The degenerating cell shows uniformly dark grey cytoplasm. Lewitsky-saline, Sudan black B, $\times 700$.

Fig. 7. The degenerating cells show Sudan black B positive cytoplasmic droplets and the developing spermatids are visible in the lumen of the seminiferous tubule. Lewitsky-saline, Sudan black B, $\times 700$.

FIG. 8. Three negatively stained perfectly spherical degenerating cells are visible amongst the cells of the seminiferous tubule. Alkaline phosphatase, $\times 700$. 
PLATE 1
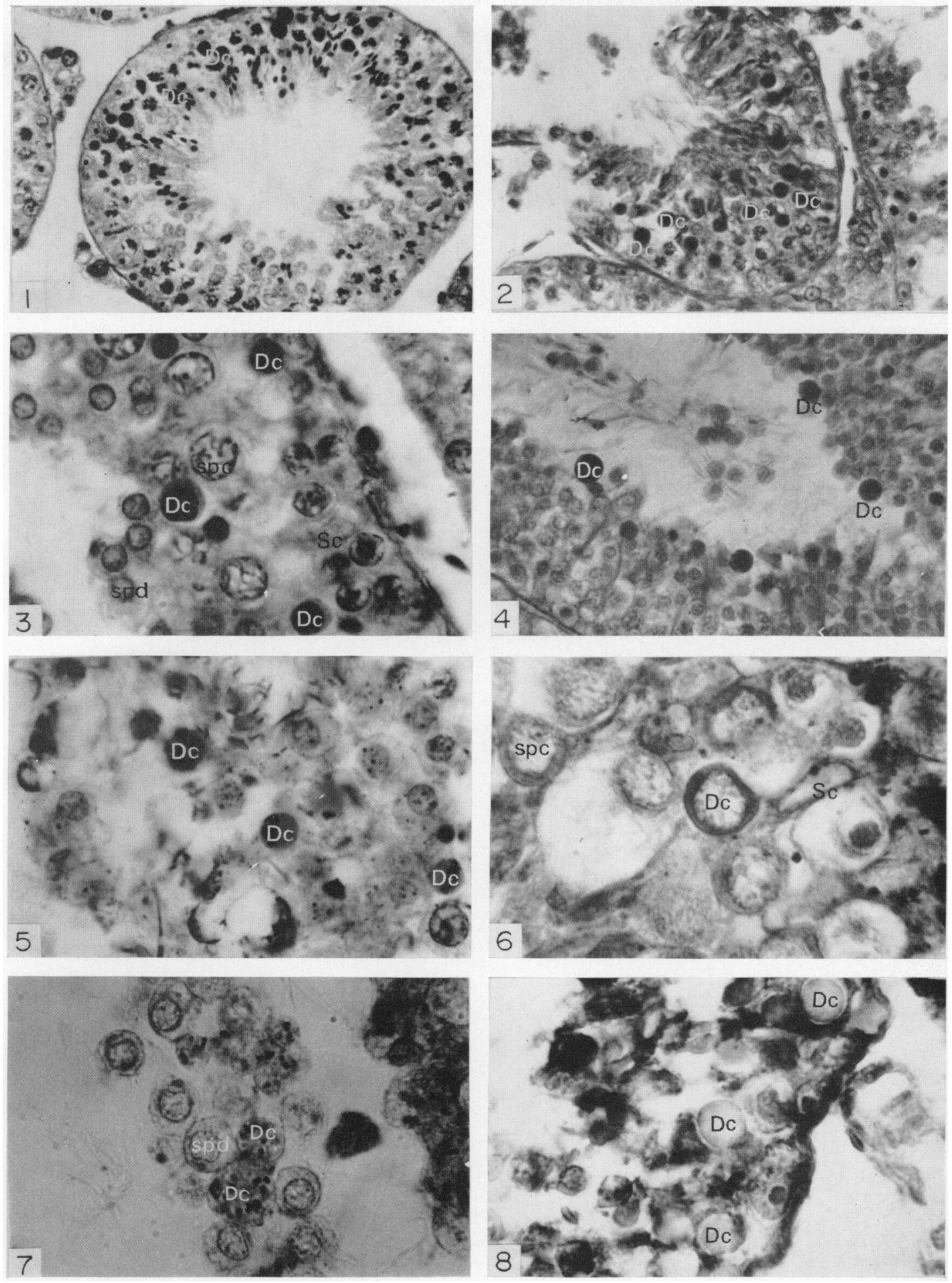

(Facing p. 360) 